ZOOLOGIA 32 (4): 281-288, August 2015

http://dx.doi.org/10.1590/S1984-46702015000400003

\title{
Termite assemblages (Blattodea: Isoptera) in a habitat humidity gradient in the semiarid region of northeastern Brazil
}

\author{
Alane A.V.O. Couto ${ }^{1}$, Auristela C. Albuquerque ${ }^{2}$, Alexandre Vasconcellos ${ }^{1} \&$ Cibele C. Castro ${ }^{3, *}$ \\ ${ }^{1}$ Laboratório de Termitologia, Departamento de Sistemática e Ecologia, Universidade Federal da Paraíba. \\ 58051-900 João Pessoa, PB, Brazil. \\ ${ }^{2}$ Laboratório de Termitologia, Departamento de Biologia, Universidade Federal Rural de Pernambuco. 52171-900 Recife, \\ PE, Brazil. \\ ${ }^{3}$ Unidade Acadêmica de Garanhuns, Universidade Federal Rural de Pernambuco. 55292-280 Garanhuns, PE, Brazil. \\ *Corresponding author. E-mail: cibelecastro@hotmail.com
}

\begin{abstract}
We compared the termite assemblages of different ecosystems in a humidity gradient. Three areas were sampled: (i) a humid montane forest; (ii) a hillside forest where shaded coffee (Coffea arabica Linnaeus, 1753) is cultivated; (iii) a seasonally dry forest (Caatinga). Active collection protocols were employed in each area during the dry and rainy seasons. The species were grouped according to their habitats and feeding habits. A total of 45 termite species belonging to 20 genera and three families were encountered. The termite fauna of the Caatinga was as rich and abundant as that of the humid forest areas, but it was distinct from it in species composition. Most termite species encountered in the montane forest were also found in the agro-ecological site, but some species were only found in the latter. The termite fauna of the Caatinga varied seasonally the most, with significantly reduced abundance during the dry period. When species richness, abundance, and species composition were considered together the climatic seasons were not found to significantly affect the termite faunas in any of the study areas. The numbers of encounters per feeding group and per habitat exploited did not differ among the different areas, or during the different seasons. Even in adjacent areas, the humidity gradient, as well as the vegetational characteristics, are reflected in differences in the termite fauna. Agro-ecological regimes can be considered viable alternatives to traditional methods of cultivation as they largely conserve the biodiversity found in non-modified environments.
\end{abstract}

KEY WORDS. Agro-ecosystem; biodiversity; Caatinga; montane forest.

Termites are important in both dry and humid tropical forests, where they are consumers of the plant necromass, helping in the processes of nutrient cycling and soil formation (LeE \& Wood 1971, Dangerfield et al. 1998, Moura et al. 2008, VASCONCELlos \& MOURA 2010). Termite species richnesses, abundances, diversity, and trophic structures, however, differ between the two kinds of ecosystems. Greater species richness (Eggleton et al. 1997, Florencio \& Diehl 2006, Vasconcellos et al. 2010) and greater density (7000 individuals $/ \mathrm{m}^{2}$ and 1100 individuals $/ \mathrm{m}^{2}$, respectively) (BIGNELl \& EGGLeTON 2000, MikLós 1998) have been observed in humid forests than in arid or semiarid environments. Differences related to feeding groups are also observed, with humus-consuming species being more abundant and vulnerable to environmental alterations in humid forests (EGGLETON et al. 1997, 2002, VAsCONCELlos 2010). Xylophagic species constitute the most abundant and vulnerable group in dry tropical forests (VASCONCELLOS et al. 2010).

The structure of the termite fauna can vary considerably between areas in the same ecosystem that have been exposed to different degrees of anthropogenic alteration (ACKERMAN et al. 2009, VASCONCELLOS et al. 2010). The modification of natural areas to form agro-ecosystems, for example, can result in significant loss of species richness, abundance, and diversity (Bandeira \& Vasconcellos 2002, Bandeira et al. 2003).

Studies have been undertaken in both humid (EGGLETON et al. 2002, VASCONCELlos 2010) and arid ecosystems separately (VAsCONCEllos et al. 2010). However, how climatic and vegetational differences alter their termite faunas has not been investigated. Until now, no study has aimed to compare adjacent wetland and arid areas. Such kind of study would be useful to understand differences in the structure of the termite fauna in response to differences in humidity. Humidity directly affects temperature and vegetation structure, which strongly influence termite assemblage structure.

Altitudinal variations in the semiarid region of northeastern Brazil can result in abrupt changes from seasonally dry vegetation (Caatinga) to humid montane forests in the space of just a few kilometers. The Caatinga is a complex vegetation type characterized by predominantly deciduous plants (BARBOSA et al. 2003, ANDRADE-Lima 2007). It is subjected to climatic conditions

2015 | Sociedade Brasileira de Zoologia | www.sbzoologia.org.br | www.scielo.br/zool All content of the journal, except where identified, is licensed under a Creative Commons attribution-type BY-NC. 
that vary from semiarid to sub-humid dry, with rainfall concentrated in a single short period (normally from 3 to 5 months). When and where it rains each year, however, is relatively unpredictable (Alves 2007). Immersed within this semiarid landscape are more humid montane forests, locally known as "brejos de altitude". They belong to the Atlantic Forest domain and occur in highlands above $700 \mathrm{~m}$ a.s.l. (SALEs et al. 1998). These sites are often utilized for agro-ecological purposes, mostly to grow flowers, coffee and other commodities.

This study sought to characterize and compare the termite assemblages found in different ecosystems along a humidity gradient, considering the climatic seasons, habitats, and termite feeding habits, to test the hypothesis that the termite faunal structure is determined by climatic and vegetational characteristics.

\section{MATERIAL AND METHODS}

The study was undertaken in the municipality of Taquaritinga do Norte, in the Agreste meso-region and Alto Capibaribe micro-region of the state of Pernambuco, northeastern Brazil. The local climate there is Tropical Rainy, with dry summers (As in Köppen system), and rainfall concentrated between February and September (Mascarenhas et al. 2005).

The fieldwork was undertaken in three areas: (1) a Montane Forest (FS) - a remnant area of upland forest located at Brejo Taquaritinga do Norte (above $700 \mathrm{~m}$ ), dominated by subperennial forest vegetation. This area covers approximately 30 ha, with a mean tree density of $0.475 / \mathrm{m}^{2}$ with diameters at soil level of $13.67 \mathrm{~cm} \pm 10.74$ (mean $\pm \mathrm{SE}$ ) $\left(7^{\circ} 54^{\prime} 21^{\prime \prime} \mathrm{S}, 36^{\circ} 01^{\prime} 11^{\prime \prime} \mathrm{W}\right)$; (2) a Coffee Plantation (CF) - an area of montane forest, also located at Brejo Taquaritinga do Norte, has been used to cultivate shaded coffee for at least 50 years, without the utilization of agro-toxins or machinery. The commercial species cultivated is Coffea arabica Linnaeus, 1753, a perennial arboreal plant of African origin. The cultivated area covers approximately 35 ha, with a mean tree density of $0.545 / \mathrm{m}^{2}$, with diameters at soil level of $10.26 \mathrm{~cm} \pm 9.78$ (mean $\pm \mathrm{SE})\left(7^{\circ} 59^{\prime} 35^{\prime \prime} \mathrm{S}, 36^{\circ} 2^{\prime} 13^{\prime \prime} \mathrm{W}\right)$; (3) Caatinga (CA) - Caatinga arboreal-shrub vegetation areas that are exposed to trampling by cattle raised at low densities. The area covers approximately $60 \mathrm{ha}$, with an average tree density of $0.33 / \mathrm{m}^{2}$ with diameters at soil level of $8.66 \mathrm{~cm} \pm 4.4$ (mean $\pm \mathrm{SE})\left(7^{\circ} 00^{\prime} 55^{\prime \prime} \mathrm{S}, 36^{\circ} 00^{\prime} 03^{\prime \prime} \mathrm{W}\right)$.

The termite fauna of each study area was sampled by establishing six $65 \times 2 \mathrm{~m}$ transects (with minimum distances of $50 \mathrm{~m}$ between them) in localities without apparent signs of disturbance. Each transect was composed of five $5 \times 2 \mathrm{~m}$ sections spaced $10 \mathrm{~m}$ from each other. A sampling effort of 01 person-hour was expended in each section. During this time, termites were searched for in various micro-habitats, such as the soil, leaf litter, in nests and on trails, on the bark of trees, and in wood in different stages of decomposition. This collection protocol was applied during both the rainy (May through
July/2011) and dry seasons (November/2011 through January/ 2012), totaling $600 \mathrm{~m}^{2}$ sampled in each of the three areas. The collected specimens were identified using the specific literature and by comparisons with specimens from the Isoptera collections at UFRPE and UFPB. The micro-habitats where the specimens were encountered were recorded during the collections. After being identified, the termite species were grouped according to their preferred food resources as (i) wood consumers; (ii) humus consumers; (iii) wood/humus consumers; and, (iv) leaf consumers. These classifications took into consideration in situ observations, analyses of the intestinal contents of the termites, the morphologies of the mandibles of 10 workers from each species, and data available in the literature (Deligne 1966, Bandeira 1989, Sena et al. 2003, Reis \& Cancello 2007, VAsConcellos 2010, Alves et al. 2011).

Characterizations of the structural physiognomies of the vegetation in each area were performed by defining two $20 \mathrm{X} 5$ $\mathrm{m}$ plots to determine the density (numbers of individuals/area) and the stem diameter at soil level (DSL) of all of the live plants with heights $\geqslant 50 \mathrm{~cm}$ and stem diameters $\geqslant 5 \mathrm{~cm}$ (adapted from VASCONCELLOS et al. 2010).

In order to confirm sufficient sampling efforts for each area in each season we utilized the first order Jackknife estimator, using EstimateS 7.5 software (COLWELl 2013), with 500 randomizations without replacing the samples. This estimator was considered by Walther \& Moore (2005) to be one of the best estimators of nonparametric species richness. To compare species richness between areas, and later between seasons within each area, rarefaction curves were constructed by randomly simulating 500 curves based on the initial data from each plot.

Additionally, the observed richness and number of encounters (used as an abundance indicator) were obtained for each area for each season. The number of encounters per transect within each study area, and subsequently for each climatic period within each study area were compared using the nonparametric Kruskal-Wallis test with the a posteriori Dunn test, run on Bioestat 5.0 software (Ayres et al. 2007).

Non-metric multidimensional scaling (NMDS) based on the Bray-Curtis coefficient of distance was performed using Primer 6.0 (ClaRKE \& WARWICK 2001) software to order the termite assemblages according to the different areas and then according to the different seasons. The same program was used to compare the structures of the termite assemblages through analysis of similarity (ANOSIM), at a 5\% level of significance.

The values of the structural variables of the vegetation in each area were examined using Lilliefors normality test followed by the Kruskal-Wallis nonparametric test, with the a posteriori Dunn test, run on Bioestat 5.0 software (Ayres et al. 2007).

The numbers of encounters per feeding group and per habitat used were compared between areas, and subsequently between climatic periods, within each study area, using the Kruskal-Wallis nonparametric test on Bioestat 5.0 software (Ayres et al. 2007). 


\section{RESULTS}

A total of 45 termite species belonging to the three principal families occurring in Brazil (Termitidae, Rhinotermitidae, and Kalotermitidae) were encountered in the three phytophysiognomies studied (Table 1). Of the total number of species, 13 (28.9\%) were encountered exclusively during the rainy period, and 5 (11.1\%) exclusively during the dry period. The greatest species richness was encountered in the coffee plantation, with 25 species, of which 14 were exclusive to that environment; followed by the montane forest area, with 17 species, of which six were exclusive to that environment; the Caatinga vegetation area had 16 species, of which 14 were exclusive to that environment.

The rarefaction curves demonstrated that there were no significant differences between the species richnesses of the three study areas or between the two climatic periods within each phytophysiognomy (Figs. 1-2).

In all of the phytophysiognomies studied Termitidae was dominant in terms of richness, having 13 (76.5\%), 17 (68\%), and $14(87.5 \%)$ species in the montane forest, coffee plantation, and Caatinga sites, respectively. Kalotermitidae was the second in terms of species richness in the montane forest and the coffee plantation; this taxon was not encountered in the Caatinga area. Rhinotermitidae was represented by only a single species in each of the three areas examined (Table 1). Termitidae was dominant in terms of the numbers of encounters in all of the phytophysiognomies examined, with 105 (92.1\%), 166 (97\%), and $122(92.4 \%)$ occurrences in the areas of montane forest, coffee plantation, and Caatinga, respectively. Kalotermitidae showed the second highest number of encounters in the montane forest and coffee plantation areas, followed by the Rhinotermitidae (Table 1).

There were no significant differences in the numbers of encounters per transect between the Caatinga vegetation area and the other areas examined, although the number of encounters was significantly greater in the coffee plantation area as compared to the montane forest (Kruskal-Wallis $\mathrm{H}=12.3, \mathrm{Gl}=$ $2, \mathrm{p}<0.01)$. The numbers of encounters did not differ significantly in the two climatic periods in the montane forest and coffee plantation areas, although significantly greater numbers of encounters were recorded in the Caatinga vegetation during the rainy season (Kruskal-Wallis $\mathrm{H}=17.17, \mathrm{Gl}=5, \mathrm{p}<0.01$ ).

The Caatinga termite fauna formed a well-defined group that was distinct from that of the other two areas (Figs. 3-4). No well-defined groups could be identified in the montane forest and coffee plantation areas, but there was an identifiable tendency toward segregation. Nonetheless, there were no discernible defined groups in those two latter areas individually during the different seasons (Figs. 3-4).

The NMDS results, considering only the areas, were confirmed by the ANOSIM (Global Test: $\mathrm{R}=0.747, \mathrm{p}=0.001$ ), with the montane forest and Caatinga areas $(\mathrm{R}=0.93, \mathrm{p}=0.001)$ and the coffee plantation and Caatinga areas $(\mathrm{R}=0.98$,
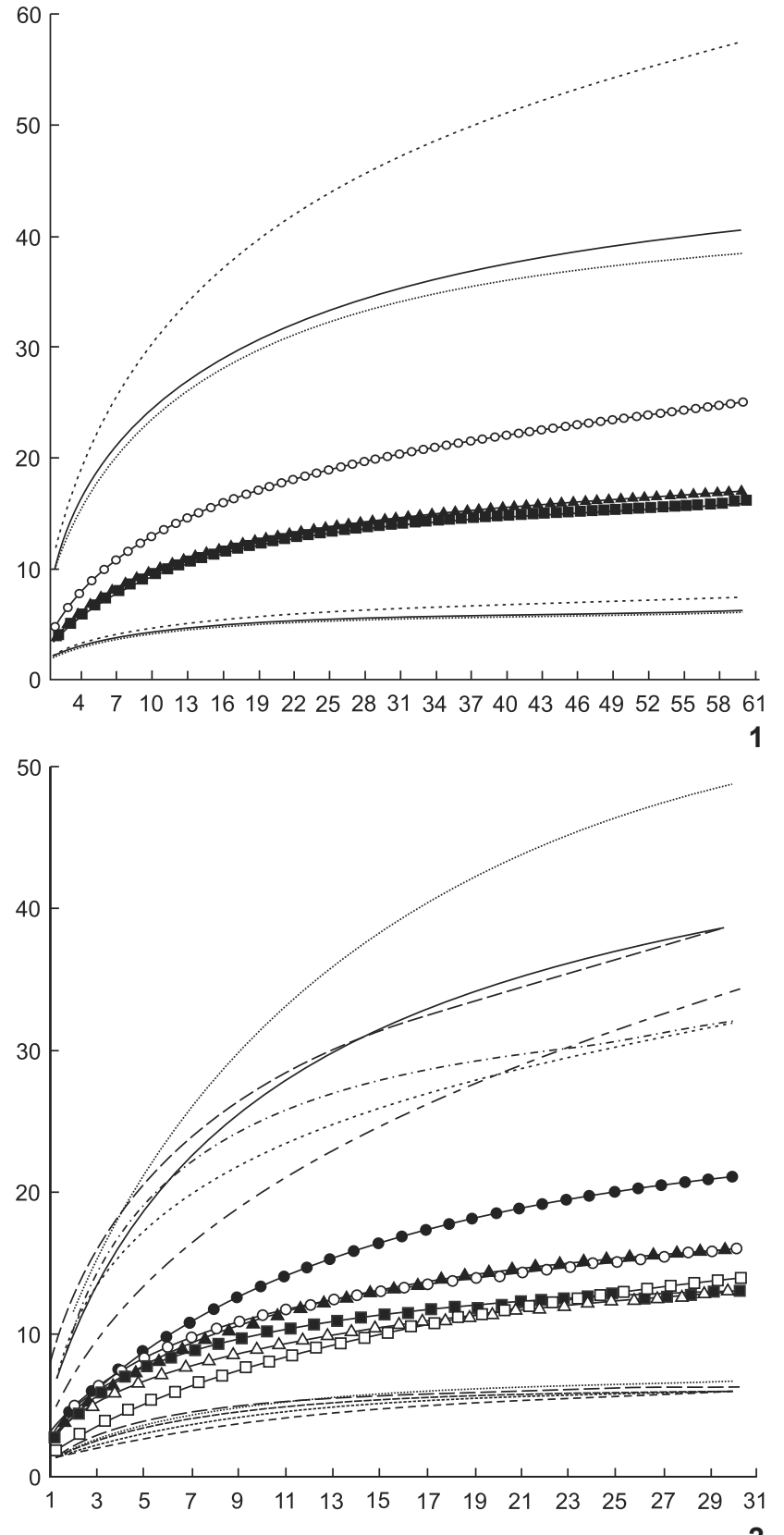

Figures 1-2. Termite species rarefaction curves and $95 \%$ confidence intervals of three sites in the semiarid region of northeastern Brazil: Montane forest, a coffee plantation, and Caatinga vegetation. (1) The curves were constructed considering only the areas themselves: Montane forest $(\boldsymbol{\Delta})$, coffee plantation $(\bigcirc)$, caatinga ( $\boldsymbol{\square})$. (2) The curves were constructed considering the climatic season: Montane forest/rain $(\mathbf{\Delta})$, montane forest/dry $(\triangle)$, coffee plantation/rain $(\boldsymbol{O})$, coffee plantation/dry $(\bigcirc)$, caatinga/rain $(\boldsymbol{\square})$, caatinga/dry $(\square)$. Collections were undertaken between April/2011 and January/2012. 
Table 1. Observed and estimated richnesses and the numbers of termite encounters in three phytophysiognomies in the semiarid region of northeastern Brazil. $\mathrm{N}$ - Number of sectors in which a species was encountered. Sobs - Observed richness. C.I. - Confidence interval. Micro-habitat ( $\mathrm{W}$ - decomposing wood, $\mathrm{S}$ - soil, L - leaf litter, $\mathrm{N}$ - nest, $\mathrm{P}$ - live plant). Feeding group (W - wood consumers, $\mathrm{H}$ - humus consumers, W/H - wood/humus consumers, L - leaf consumers).

\begin{tabular}{|c|c|c|c|c|c|c|c|c|}
\hline \multirow{2}{*}{ Family/Species } & \multicolumn{2}{|c|}{ Montane forest } & \multicolumn{2}{|c|}{ Coffee plantation } & \multicolumn{2}{|c|}{ Caatinga } & \multirow{2}{*}{ Micro-habitat } & \multirow{2}{*}{ Feeding group } \\
\hline & $N($ rain) & $N($ dry) & $N$ (rain) & $\mathrm{N}$ (dry) & $N$ (rain) & $N($ dry) & & \\
\hline \multicolumn{9}{|l|}{ Kalotermitidae } \\
\hline Glyptotermes sp. & 1 & 0 & 2 & 0 & 0 & 0 & W & W \\
\hline Neotermes paraensis & 3 & 1 & 0 & 0 & 0 & 0 & W & W \\
\hline Neotermes fulvescens & 0 & 2 & 0 & 0 & 0 & 0 & w & w \\
\hline Neotermes sp. & 0 & 0 & 1 & 0 & 0 & 0 & W & W \\
\hline Rugitermes sp. & 0 & 0 & 1 & 0 & 0 & 0 & W & w \\
\hline \multicolumn{9}{|l|}{ Rhinotermitidae } \\
\hline Heterotermes longiceps & 1 & 1 & 0 & 1 & 0 & 0 & W & w \\
\hline Heterotermes sulcatus & 0 & 0 & 0 & 0 & 7 & 3 & w & w \\
\hline \multicolumn{9}{|l|}{ Termitidae: Apicotermitinae } \\
\hline Anoplotermes sp. A & 4 & 10 & 0 & 0 & 0 & 0 & $\mathrm{~S} / \mathrm{W}$ & $\mathrm{H}$ \\
\hline Anoplotermes sp. B & 4 & 0 & 3 & 14 & 0 & 0 & s & $\mathrm{H}$ \\
\hline Anoplotermes sp. C & 0 & 0 & 4 & 0 & 0 & 0 & S & $\mathrm{H}$ \\
\hline Anoplotermes sp. D & 0 & 0 & 2 & 8 & 0 & 0 & S & $\mathrm{H}$ \\
\hline Anoplotermes sp. E & 0 & 0 & 5 & 0 & 0 & 0 & S & $\mathrm{H}$ \\
\hline Anoplotermes sp. F & 0 & 0 & 0 & 0 & 11 & 11 & S & $\mathrm{H}$ \\
\hline Aparatermes sp. A & 3 & 1 & 0 & 0 & 0 & 0 & S & $\mathrm{H}$ \\
\hline Aparatermes sp. B & 2 & 2 & 4 & 2 & 0 & 0 & S & $\mathrm{H}$ \\
\hline Aparatermes sp. C & 3 & 0 & 0 & 0 & 0 & 0 & S & $\mathrm{H}$ \\
\hline Aparatermes sp. D & 0 & 0 & 1 & 0 & 0 & 0 & S & $\mathrm{H}$ \\
\hline Aparatermes sp. E & 0 & 0 & 1 & 0 & 0 & 0 & S & $\mathrm{H}$ \\
\hline Aparatermes sp. F & 0 & 0 & 2 & 1 & 0 & 0 & S & $\mathrm{H}$ \\
\hline Aparatermes sp. G & 0 & 0 & 0 & 0 & 5 & 4 & S & $\mathrm{H}$ \\
\hline Aparatermes sp. $\mathrm{H}$ & 0 & 0 & 0 & 0 & 4 & 0 & S & $\mathrm{H}$ \\
\hline Aparatermes sp. I & 0 & 0 & 0 & 4 & 0 & 0 & S & $\mathrm{H}$ \\
\hline Grigiotermes sp. A & 1 & 0 & 0 & 0 & 0 & 0 & s & $\mathrm{H}$ \\
\hline Grigiotermes sp. B & 0 & 0 & 2 & 0 & 0 & 0 & s & $\mathrm{H}$ \\
\hline Grigiotermes sp. C & 0 & 0 & 0 & 0 & 5 & 1 & S & $\mathrm{H}$ \\
\hline Grigiotermes sp. D & 0 & 0 & 0 & 0 & 3 & 3 & S & $\mathrm{H}$ \\
\hline Ruptitermes silvestrii & 0 & 0 & 0 & 0 & 13 & 3 & S & $\mathrm{W} / \mathrm{H}$ \\
\hline Ruptitermes cf. reconditus & 0 & 0 & 3 & 8 & 0 & 0 & s & $\mathrm{L}$ \\
\hline Ruptitermes sp. & 0 & 0 & 0 & 0 & 0 & 1 & S & L \\
\hline \multicolumn{9}{|l|}{ Termitidae: Nasutitermitinae } \\
\hline Constrictotermes cyphergaster & 0 & 0 & 0 & 0 & 16 & 19 & $N$ & w \\
\hline Diversitermes sp. & 10 & 14 & 7 & 7 & 0 & 1 & $\mathrm{~S} / \mathrm{W} / \mathrm{L}$ & $\mathrm{W} / \mathrm{H}$ \\
\hline Nasutitermes corniger & 11 & 10 & 22 & 24 & 0 & 0 & W/L/N/P & w \\
\hline Nasutitermes jaraguae & 6 & 4 & 6 & 5 & 0 & 0 & W/L & w \\
\hline Nasutitermes sp. & 0 & 0 & 0 & 0 & 0 & 2 & w & W \\
\hline Subulitermes sp. & 0 & 0 & 0 & 1 & 0 & 0 & s & $\mathrm{H}$ \\
\hline Velocitermes sp. & 1 & 0 & 1 & 2 & 0 & 0 & L & $\mathrm{L}$ \\
\hline & & & & & & & & Continues \\
\hline
\end{tabular}


Table 1. Continued.

\begin{tabular}{|c|c|c|c|c|c|c|c|c|}
\hline \multirow{2}{*}{ Family/Species } & \multicolumn{2}{|c|}{ Montane forest } & \multicolumn{2}{|c|}{ Coffee plantation } & \multicolumn{2}{|c|}{ Caatinga } & \multirow{2}{*}{ Micro-habitat } & \multirow{2}{*}{ Feeding group } \\
\hline & $N($ rain) & $N($ dry) & $N$ (rain) & $N($ dry) & $N$ (rain) & $\mathrm{N}$ (dry) & & \\
\hline \multicolumn{9}{|l|}{ Termitidae: Syntermitinae } \\
\hline Ibitermes curupira & 3 & 4 & 0 & 1 & 0 & 0 & S & $\mathrm{H}$ \\
\hline \multicolumn{9}{|l|}{ Termitidae: Termitinae } \\
\hline Amitermes amifer & 5 & 5 & 6 & 8 & 5 & 2 & w & W \\
\hline Amitermes sp. & 0 & 0 & 0 & 0 & 7 & 0 & W & W \\
\hline Dentispicotermes sp. & 0 & 0 & 2 & 5 & 0 & 0 & s & $\mathrm{H}$ \\
\hline Inquilinitermes fur & 0 & 0 & 0 & 0 & 1 & 1 & $\mathrm{~N}$ & $\mathrm{~W} / \mathrm{H}$ \\
\hline Inquilinitermes microcerus & 0 & 0 & 0 & 0 & 1 & 1 & $\mathrm{~N}$ & $\mathrm{H}$ \\
\hline Neocapritermes opacus & 2 & 0 & 3 & 1 & 0 & 0 & s & $\mathrm{W} / \mathrm{H}$ \\
\hline Orthognathotermes sp. & 0 & 0 & 1 & 0 & 0 & 0 & s & $\mathrm{H}$ \\
\hline Termes medioculatus & 0 & 0 & 0 & 0 & 1 & 1 & w & $\mathrm{W} / \mathrm{H}$ \\
\hline Sobs & & 11 & 21 & 16 & 13 & 14 & & \\
\hline Jackknife 1 (mean \pm C.I.) & $23.5 \pm 5.5$ & $13.5 \pm 4.4$ & $26 \pm 3.3$ & $21 \pm 4.7$ & $18.1 \pm 6.1$ & $20.6 \pm 4.3$ & & \\
\hline Numbers of encounters & 60 & 54 & 79 & 92 & 79 & 53 & & \\
\hline
\end{tabular}
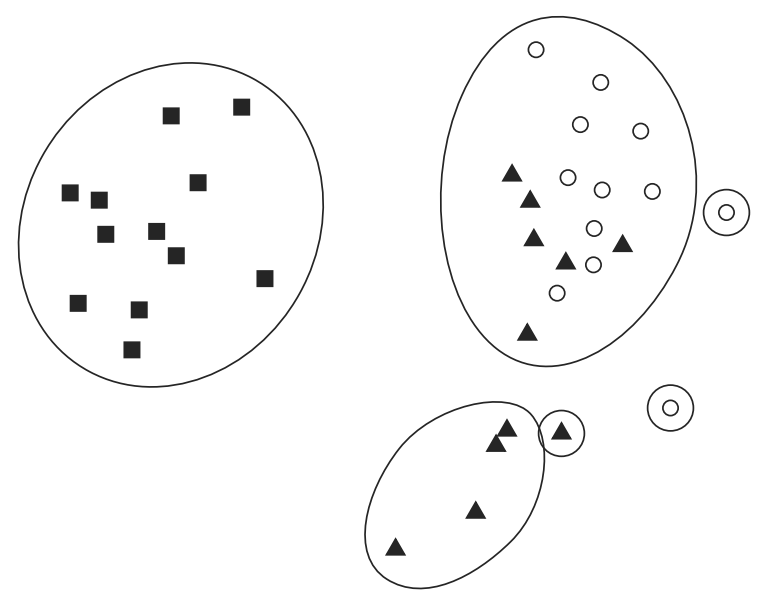
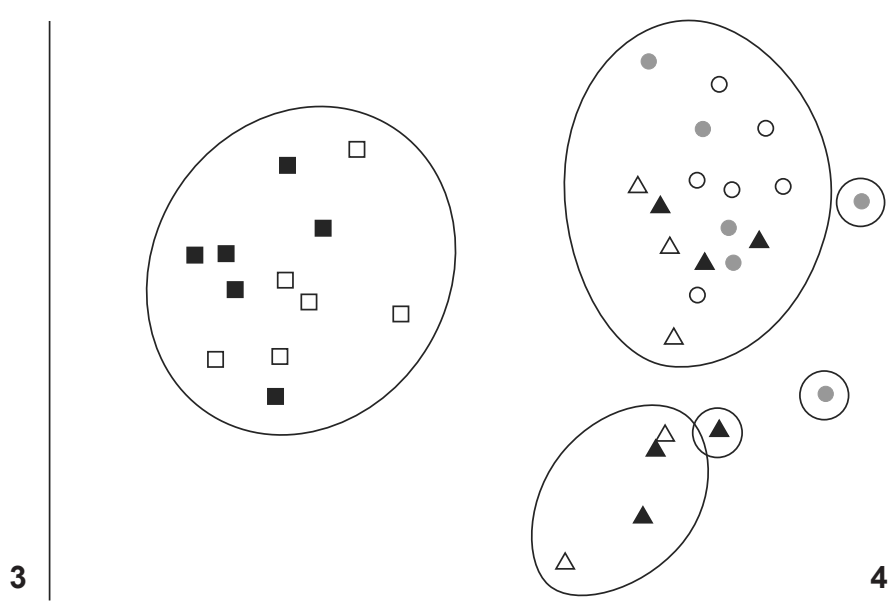

Figures 3-4. Non-metric multidimensional scaling of the termite fauna of three phytophysiognomies in the Agreste region of the state of Pernambuco, northeastern Brazil. Groups formed using a $40 \%$ level of similarity. (3) Ordination performed considering only the phytophysiognomies: Montane forest $(\boldsymbol{\Delta})$, coffee plantation $(\bigcirc)$, caatinga $(\mathbf{\square})$. (4) Ordination performed considering the phytophysiognomies and seasonal climatic variations: Montane forest/rain $(\boldsymbol{\Delta})$, montane forest/dry $(\triangle)$, coffee plantation/rain $(\bullet)$, coffee plantation/dry $(\bigcirc)$, caatinga/rain ( $\square$ ), caatinga/dry $(\square)$. Collections were undertaken between April/2011 and January/2012.

$\mathrm{p}=0.001)$ demonstrating lower similarity as compared to the montane forest and coffee plantation areas $(\mathrm{R}=0.265, \mathrm{p}=$ 0.001). The collection period did not affect the compositions of the termite assemblages encountered (Global test: 0.595, p $=0.001)$, and the same results were found for the montane forest $(\mathrm{R}=-0.064, \mathrm{p}=0.64)$, coffee plantation $(\mathrm{R}=0.002, \mathrm{p}=$ $0.48)$, and Caatinga sites separately $(\mathrm{R}=0.165, \mathrm{p}=0.11)$.

In general, wood consumers were the most abundant, followed by humus consumers. The numbers of encounters per feeding group did not vary significantly among the different study areas (Kruskal-Wallis $\mathrm{H}=0.47, \mathrm{Gl}=2, \mathrm{p}=0.79$ ). Likewise, there were no significant differences in terms of numbers of encounters per feeding group during the different seasons within each of the different study areas (Kruskal-Wallis $\mathrm{H}=$ $1.69, \mathrm{Gl}=5, \mathrm{p}=0.89$ ).

In the montane forest area the termites were mostly collected in decomposing wood and in the soil. The greatest numbers of occurrences in the coffee plantation and the Caatinga 
vegetation, on the other hand, were in the soil and in decomposing wood, respectively. The numbers of encounters per habitat did not vary significantly among the study areas (Kruskal-Wallis $\mathrm{H}=0.38, \mathrm{Gl}=2, \mathrm{p}=0.82$ ). There were also no significant differences in terms of the numbers of encounters per habitat during the different seasonal periods within each study area (Kruskal-Wallis $\mathrm{H}=0.92, \mathrm{Gl}=5, \mathrm{p}=0.97$ ).

The average densities of trees did not differ significantly among the different study areas $(\mathrm{H}=2.57, \mathrm{Gl}=2, \mathrm{p}=0.27)$; the montane forest demonstrated significantly greater DSL values than the other areas $(\mathrm{H}=18.98, \mathrm{Gl}=2, \mathrm{p}=0.0002)$.

\section{DISCUSSION}

The termite species richness observed in the Caatinga vegetation area (16 species) was greater than that reported by Alves et al. (2011), who noted a total of 10 different species in three areas of Caatinga in northeastern Brazil, but less than that reported by VASCONCELLOS et al. (2010), who noted a total of 26 termite species in three areas of Caatinga exposed to different degrees of anthropogenic disturbance in the same region. These significantly different values reflect the heterogeneity of Caatinga sites, which are determined by their climates, geomorphologies, and vegetation types (Velloso et al. 2002).

The termite species richness in the montane forest area of the present study (17 species) was slightly lower to those reported by Bandeira \& Vasconcellos (2002) and Bandeira et al. (2003). These researchers collected in areas of primary vegetation, and in vegetation in different stages of regeneration (18 and 23 species, respectively) in a montane forest situated in the Agreste region of the state of Pernambuco (northeastern Brazil). It was also lower than that found by CANCELLo et al. (2014) in Atlantic Forest sites in nearby latitudes, but it was similar to that found between $9^{\circ}$ and $18^{\circ}$. The same study suggested that temperature is the strongest predictor of the structure of termite assemblages in Atlantic Forest and is negatively correlated with richness. Therefore, their results could be related to a cooler altitude climate.The species richness observed in the coffee plantation site ( 25 species) of this study was much greater than in other areas modified to form agro-ecosystems. BANDEIRA \& VAsconcellos (2002) and BANDeira et al. (2003), for example, reported seven and five termite species, respectively, in a banana plantation at an area of montane forest in the Agreste region of the state of Pernambuco. In that case, the different crop and sampling effort (ours was greater) may have affected the result.

The dominance of Termitidae, in terms of both species richness and the numbers of encounters in all of the areas, can be largely explained by the fact that this is the largest and most diversified termite family, comprising approximately $75 \%$ of all currently known species (Costa-Leonardo 2002). The absence of Kalotermitidae in the Caatinga site may well be related to its vegetation cover - as this area contained plants with the smallest mean DSL, which favors a greater incidence of solar radiation reaching the ground and, consequently, greater soil surface temperatures. Any wood on the soil surface (the substrate utilized by the representatives of this family) would therefore be hot and dry and less favorable to the survival and success of these insects (VAsCONCELlos 2010).

Although tropical humid forests generally demonstrate the greatest richnesses and abundances of termite species, no significant differences were observed between the Caatinga vegetation and the other phytophysiognomies examined here. The Brejo de Taquaritinga forest, in particular, has been subjected to increasing environmental degradation that has resulted in a large loss of plant richness (Rodal et al. 1998) that would likewise have affected its termite assemblages.

Most studies that have compared areas of native vegetation in montane forest regions (BANDEIRA \& VASCONCELlos 2002) or in other humid forest sites (GILLISON et al. 2003) with modified agro-ecosystem sites have shown that the termite fauna was negatively altered, with decreases in species richness and abundance. In the present study, however, there was no significant difference in richness between the coffee plantation and the montane forest, and the number of encounters of termites in the coffee plantation was actually greater than in the area of montane forest. Similar results were reported by ACKERMAN et al. (2009) in their comparison of a primary forest area with two modified agro-ecosystem sites in the Amazon region, as no significant alterations were noted in terms of richnesses of the termite assemblages. These authors suggested that their results reflected only local characteristics and not a general pattern - but as the same situation was observed in the present study, it is possible that the disturbances caused by the agro-ecological regime favored the appearance of new niches and altered the abundance of some species, thus allowing the expansion of populations that had been suppressed by interspecific competition.

The composition of the Caatinga termite assemblage was quite distinct in relation to the other areas, as only two of its species were not exclusive to that site (Diversitermes sp. and Amitermes amifer Silvestri, 1901). This result confirms a tendency for significant differences in the species compositions of the termite fauna of humid and arid environments, as noted in other comparisons (BANDEIRA \& VASCONCELLOS 2002, BANDEIRA et al. 2003). The present work also indicates that these differences are maintained even when the environments are directly adjacent.

There were similarities between the species richnesses of the montane forest and the coffee plantation (11 species). Similarly, other surveys undertaken in tropical humid forests, such as by BANDEIRA et al. (2003) in an area of montane forest, and by Ackerman et al. (2009) in a forest in the Amazon region, demonstrated that many termite species were able to survive even after the installation of agro-ecological regimes.

The richness and abundance of the soil termite fauna did not vary significantly during the different seasons in the montane forest and coffee plantation sites, although a negative correlation was observed between those descriptors and short-term 
rainfall - since after a rainy period the soil is flooded, impeding the movement of the termites to the surface. These results corroborated those of DiвоG et al. (1998) in a tropical humid forest.

In spite of the fact that seasonal changes did not affect species richness in the Caatinga site, the numbers of termite encounters were significantly lower during the dry period linked to temperature increases, lower relative humidity of the air, and loss of leaf biomass in the Caatinga during the dry period (BARBosa et al. 2003). Leaf loss exposes the soil surface to more solar radiation and drying, affects food resource availability and decreases the intensity of foraging activities (VASCONCELlos et al. 2007).

The greater numbers of encounters of wood consuming termites, followed by humus consumers, in the Caatinga and coffee plantation sites, reported here, corroborate other works undertaken in areas of Caatinga (Alves et al. 2011, VASCONCELLOS et al. 2010) and montane forest sites that had been modified as agro-ecosystems (BANDEIRA \& Vasconcellos 2002, Bandeira et al. 2003). The large number of wood consuming termites in the montane forest area, however, conflicts with reports on other areas of non-modified montane forest sites (BANDEIRA \& Vasconcellos 2002, Bandeira et al. 2003), Atlantic Forest sites (VAsConcellos 2010), and other humid tropical forest areas in Africa (EgGLETon et al. 2002) where humus consuming species predominate. These same studies demonstrated that wood consuming species were predominant in areas of secondary forest, which reinforces the idea that the area of montane forest studied here was being impacted by anthropogenic pressures.

In conclusion, the following observations should be emphasized: (i) the Caatinga termite fauna was as rich and abundant as that of the humid forest, although it had a distinct composition - demonstrating that climatic and vegetational characteristics dictated faunal differences even though the areas were adjacent, and that it will be important to adopt measures that can guarantee the conservation and biodiversity of both ecosystems; (ii) the shaded coffee agro-ecological regime demonstrated the capacity to maintain most of the termite fauna found in the neighboring area of non-modified montane forest and even harbored additional species - suggesting that the establishment of economically valuable cultures in agro-ecological regimes could conserve important part of the biodiversity found in non-modified environments; (iii) only the termite fauna of the Caatinga demonstrated alterations during seasonal changes, with significantly reduced termite abundances during the dry period. However, when species richness, abundance and composition were considered together, seasonal changes did not significantly affect the termite fauna in any of the study areas.

\section{ACKNOWLEDGEMENTS}

The authors would like to thank the Universidade Federal Rural de Pernambuco (UFRPE) for its support; the Coordenação de Aperfeiçoamento de Pessoal de Nível Supe- rior (CAPES) for the grant awarded to the first author; and the trainees of the Laboratório de Termitologia of UFRPE for their help during the fieldwork.

\section{LITERATURE CITED}

Ackerman IL, Constantino R, Gauch Jr HG, Lehmann J, Riha SJ, Fernandes ECM (2009) Termite (Insecta: Isoptera) species composition in a primary rain forest and agroforests in Central Amazonia. Biotropica 41(2): 226-233. doi: 10.1111/ j.1744-7429.2008.00479.x

Andrade-Lima D (2007) Estudos fitogeográficos de Pernambuco. Anais da Academia Pernambucana de Ciência Agronômica 4: 243-274.

Alves JJA (2007) Geoecologia da Caatinga no semi-árido do Nordeste brasileiro. Climatologia e estudos da paisagem. Climep: Climatologia e Estudos da Paisagem 2: 58-69.

Alves WF, Mota AS, Lima RAA, Bellezoni R, Vasconcellos A (2011) Termites as bioindicators of habitat quality in the Caatinga, Brazil: is there agreement between structural habitat variables and the sampled assemblages? Neotropical Entomology 40: 39-46. doi: 10.1590/S1519-566X2011000100006

Ayres M, Ayres Jr M, Ayres DL, Santos AA (2007) BIOESTAT Aplicações estatísticas nas áreas das ciências biomédicas. Belém, ONG Mamirauá, 364p.

BANDEIRA AG (1989) Análise da termitofauna (Insecta: Isoptera) de uma floresta primária e de uma pastagem na Amazônia Oriental, Brasil. Boletim do Museu Paraense Emílio Goeldi: Zoologia 5: 225-241.

Bandeira AG, Vasconcellos A (2002) A quantitative survey of termites in a gradient of disturbed highland forest in northeastern Brazil (Isoptera). Sociobiology 39: 429-439.

Bandeira AG, Vasconcellos A, Silva M, Constantino R (2003) Effects of habitat disturbance on the termite fauna in a highland humid forest in the Caatinga domain, Brazil. Sociobiology 42: 1-11.

Bignell DE, Eggleton P (2000) Termites in ecosystems, p. 363387. In: Abe T, Higashi M, Bignell DE (Eds.). Termites: Evolution, Sociality, Symbiosis, Ecology. Durdrecht, Kluwer Academic Publication.

Barbosa DCA, Barbosa MCA, Lima LMC (2003) Fenologia de espécies lenhosas da Caatinga, p. XIII-XVII. In: LeAL IR, Tabarelli M, Silva JMC (Eds.). Ecologia e conservação da Caatinga. Recife, Ed. Universitária UFPE.

Cancello EM, Silva RR, Vasconcellos A, Reis YT, Oliveira LM (2014) Latitudinal Variation in Termite Species Richness and Abundance along the Brazilian Atlantic Forest Hotspot. Biotropica 46(4): 441-450. doi: 10.1111/btp.12120

CLARKE KR, WARWICK RM (2001) Change in marine communities: an approach to statistical analyses and interpretation. Plymouth, PRIMER-E, 91p.

Colwell RK (2013) EstimateS: Statistical estimation of species richness and shared species from samples. Version 9.1. 
Available online at: http://viceroy.eeb.uconn.edu/estimates [Accessed: 16/7/2013]

Costa-Leonardo AM (2002) Cupins-praga: morfologia, biologia e controle. Rio Claro, UNESP, 128p.

Dangerfild JM, Maccarthy TS, Ellery WN (1998) The mound building termite Macrotermes michaelseni as an ecosystem engineer. Journal of Tropical Ecology 14(4): 507-520.

Deligne J (1966) Caractères adaptatifs au regime alimentaire dans la mandíbula des termites (Insectes: Isoptères). Comptes Rendus de I'Académie des Sciences 263: 13231325.

Dibog L, Eggleton P, Forzi F (1998) Seasonality of soil termites in a humid tropical forest, Mbalmayo, southern Cameroon. Journal of Tropical Ecology 14(8): 841-850. doi: 10.1017/ S0266467498000601

Eggleton P, Homathevi R, Jeeva D, Jones DT, Davies RG, Maryati M (1997) The species richness and composition of termites (Isoptera) in primary and regenerating lowland Dipterocarp forest in Sabah, East Malaysia. Ecotropica 3: 119-128.

Eggleton P, Bignell De, Hauser S, Dibog L, Norgrove L, Madong B (2002) Termite diversity across an anthropogenic disturbance gradient in the humid forest zone of West Africa. Agriculture, Ecosystems and Environment 90(2): 189-202. doi: 10.1016/S0167-8809(01)00206-7

Florencio DF, Diehl E (2006) Termitofauna (Insecta, Isoptera) em Remanescentes de Floresta Estacional Semidecidual em São Leopoldo, Rio Grande do Sul, Brasil. Revista Brasileira de Entomologia 50(4): 505-511. doi: 10.1590/S008556262006000400011

Gillison AN, Jones DT, Susilo FX, Bignell DE (2003) Vegetation indicates diversity of soil macroinvertebrates: a case study with termites along a land-use intensification gradient in lowland Sumatra. Organisms Diversity and Evolution 3(2): 111-126. doi: 10.1078/1439-6092-00072

Lee KE, Wood TG (1971) Termites and Soils. New York, Academic Press, 251p.

Mascarenhas JC, Beltrão BA, Souza Jr LC, Galvão MJTG, Pereira SN, Miranda JLF (2005) Projeto cadastro de fontes de abastecimento por água subterrânea. Diagnóstico do município de Taquaritinga do Norte, estado de Pernambuco. Recife, CPRM/PRODEEM, 11p.

Miklós AAW (1998) Papel de cupins e formigas na organização e na dinâmica da cobertura pedológica, p. 227-242. In: FonTES LR, Berti-Filho E (Eds.). Cupins: o desafio do conhecimento. Piracicaba, FEALQ.

Moura FMS, Vasconcellos A, Araújo VFP, Bandeira AG (2008)
Consumption of vegetal organic matter by Constrictotermes cyphergaster (Isoptera, Termitidae, Nasutitermitinae) in a site of Caatinga, Northeastern Brazil. Sociobiology 51: 181-189.

ReIs YT, CANCELlo EM (2007) Riqueza de cupins (Insecta, Isoptera) em áreas de Mata Atlântica primária e secundária do sudeste da Bahia. Iheringia: Zoologia 97(3): 229-234. doi: 10.1590/S0073-47212007000300001

Rodal MJN, Sales MF, Mayo SJ (1998) Florestas serranas de Pernambuco: localização e conservação dos remanescentes dos brejos de altitude. Recife, Universidade Federal Rural de Pernambuco, 30p.

Sales MF, Mayo SJ, Rodal MJN (1998) Plantas vasculares das florestas serranas de Pernambuco: um checklist da flora ameaçada dos brejos de altitude, Pernambuco, Brasil. Recife, Universidade Federal Rural de Pernambuco, 130p.

Sena JM, Vasconcellos A, Bezerra-Gusmão MA, Bandeira AG (2003) Assemblage of termites in a fragment of Cerrado on the coast of Paraiba State, Northeast Brazil (Isoptera). Sociobiology 42: 753-760.

VAsConcellos A (2010) Biomass and abundance of termites in three remnant areas of Atlantic Forest in northeastern Brazil. Revista Brasileira de Entomologia 54(3): 455-461. doi: 10.1590/S0085-56262010000300017

Vasconcellos A, Moura FMS (2010) Wood litter consumption by three species of termite Nasutitermes in an area of Atlantic Forest in northeastern Brazil. Journal of Insect Science 10: 1-9. doi: 10.1673/031.010.7201

Vasconcellos A, Araujo VFP, Moura FMS, Bandeira AG (2007) Biomass and population structure of Constrictotermes cyphergaster (Silvestri) (Isoptera: Termitidae) in the dry forest of caatinga, northeastern Brazil. Neotropical Entomology 36(5): 693-698. doi: 10.1590/S1519-566X2007000500009

Vasconcellos A, Bandeira AG, Moura FMS, Araújo VFP, BezerraGusmão MAB, Constantino R (2010) Termite assemblages in three habitats under different disturbance regimes in the semiarid Caatinga of NE Brazil. Journal of Arid Environments 74(2): 298-302. doi: 10.1016/j.jaridenv.2009.07.007

Velloso AL, Sampaio EVSB, Pareyn FGC (2002). Ecorregiões propostas para o bioma Caatinga. Recife, Associação Plantas do Nordeste, Instituto de Conservação Ambiental, The Nature Conservancy Brasil, 76p.

Walther BA, Moore JL (2005) The concepts of bias, precision and accuracy, and their use in testing the performance of species richness estimators, with a literature review of estimator performance. Ecography 28(6): 815-829. doi: 10.1111/j.2005.0906-7590.04112.x

Submitted: 5 February 2015

Received in revised form: 6 May 2015

Accepted: 16 May 2015

Editorial responsibility: Gabriel L.F. Mejdalani

ZOOLOGIA 32 (4): 281-288, August 2015 